\title{
Viðhorf Íslendinga til lyfja og lyfjameðferðar
}

\author{
Hlíf Vilhelmsdóttir ${ }^{1,2}$ lyfjafræðingur, Magnús Jóhannsson² læknir
}

\section{Á G R I P}

Tilgangur: Að kanna viðhorf Íslendinga til lyfja.

Aðferðir: Spurningalistinn The Beliefs about Medicines Questionnaire $(B M Q)$ var pýddur, gildaður og notaður til að kanna viðhorf Íslendinga til lyfja. Einnig var spurt um heilsufar og sjúkdóma pátttakenda. Úrtakið var 1500 Íslendingar á aldrinum 18-75 ára sem fengið var úr nethópi Félagsvísindastofnunar Háskóla Íslands.

Niðurstöður: Svarhlutfallið var 61,6\%. Flestir Íslendingar eru jákvæðir gagnvart lyfjum og treysta peim yfirleitt. Sjúklingar með langvinna sjúkdóma eru jákvæðari en ađrir pátttakendur og taka síður undir fullyrðingar um skaðsemi og ofnotkun lyfja. Menntun hefur mikil áhrif á viðhorfin með peim hætti að fólk með minni menntun ber minna traust til lyfja. Kyn eða aldur hafa ekki teljandi áhrif á við̌horfin.

Umræður: Niðurstöðurnar gefa góða mynd af viðhorfum Íslendinga til lyfja og lyfjameðferðar. Pær gætu skapað grundvöll umbótastarfs fyrir klíníska vinnu og til hagræðingar fyrir heilbrigðiskerfið. Slík vinna gæti stuðlað að málefnalegri umræðu um pátt lyfja í meðferð sjúkdóma, vanda tengdan meðferðarfylgni og betri samskiptum lækna við sjúklinga og lyfjafyrirtæki.

\section{Inngangur}

Viðhorf fólks til lyfja ræður talsvert miklu um meðferðarfylgni í ýmsum langvinnum sjúkdómum og er talið vega pyngra en klínískir, félagslegir og lýðfræðilegir pættir. ${ }^{1,2}$ Prátt fyrir að réttum lyfjum sé ávísað réttum sjúklingi má vera að árangur verði síðri, samrýmist meðferðin ekki viðhorfum sjúklingsins. Viðhorf sjúklinga gagnvart lyfjum, lyfjaávísunum og jafnvel lyfjafyrirtækjum getur haft mikil áhrif á hvort sjúklingar gangist undir lyfjameðferð samkvæmt ábendingum og hvort meðferðarfylgni aukist., Peir sem hafa sterkastar skoðanir í pessum efnum geta mögulega haft áhrif á vini og vandamenn sem taka lyf og peirra meðferðarfylgni. Neikvæð viðhorf til lyfja, til dæmis áhyggjur af aukaverkunum, geta valdið slakri meðferðarfylgni. ${ }^{1}$ Með pví að kortleggja og auka skilning á viðhorfum sjúklinga til lyfja geta fundist leiðir til að bæta meðferðarfylgni og klíníska útkomu. Ef hægt væri að átta sig á áhrifapáttum viðhorfa til lyfja mætti finna leiðir til að gera pau jákvæðari. Рað yrði gagnlegt í próun á inngripum til að bæta meðferðarfylgni. ${ }^{5}$

The Beliefs about Medicines Questionnaire spurningalistinn (BMQ) BMQ-spurningalistinn var próaður í Bretlandi árið 1999 og er notaður til að kanna viðhorf sjúklinga til lyfja í tengslum við meðferð langvinnra sjúkdóma. ${ }^{4}$ Ákveðnir pættir virðast hafa áhrif á viðhorfin, til að mynda uppruni fólks, menning ${ }^{6,7}$ og menntun.

'Lyfjafræðideild, ²annsóknastofu i l lyfja-og eiturefnafræði við Háskóla Íslands. Fyrirspurnum svarar Hlíf Vilhelmsdóttir hlif84@gmail.com

https://doi.org/10.17992/lbl.2017.02.120

Greinin barst 7. september 2016, sampykkt til birtingar 2. janúar 2017.
Betur menntað fólk hefur jafnan betri pekkingu á sjúkdómi sínum og meðferðinni og er viðhorf pess til lyfja jákvæðara. ${ }^{8}$ Fólk með litla pekkingu á lyfjum sínum lítur oftar á lyf sem hættuleg heldur en peir sem hafa góða pekkingu. ${ }^{9}$ Gæði sambands læknis og sjúklings með langvinnan sjúkdóm virðast ráða miklu um viðhorf sjúklings til lyfjameðferðar. Mikið getur unnist fyrir árangur meðferðar með pví að bæta slík tengsl.,10,11 Samskipti lækna og lyfjafyrirtækja geta einnig haft áhrif á viðhorfin. Sjúklingar líta svo á að gjafir til lækna frá lyfjafyrirtækjum séu algengar og petta veldur peim áhyggjum. Sumir sjúklingar telja að samskiptin hafi áhrif á ákvarðanir lækna í lyfjameðferðinni. Petta ógnar pví trausti sem peir bera til lækna sinna og heilbrigðiskerfisins., ${ }^{3,12,13}$

BMQ hefur verið notaður til að meta viðhorf ýmissa sjúklingahópa með langvinna sjúkdóma, svo sem astma, ${ }^{1,14}$ hjarta- og æðasjúkdóma, ${ }^{15-18}$ geðsjúkdóma, ${ }^{19,20}$ krabbamein, ${ }^{21,22}$ gigtarsjúkdóma ${ }^{23,24}$ og fleiri. ${ }^{25}$

Markmið rannsóknarinnar var að kanna viðhorf Íslendinga til lyfja og lyfjameðferðar sem hefur lítið verið kannað á Íslandi og aldrei áður með BMQ. Viðhorf fólks með ákveðna langvinna sjúkdóma (hjarta- og æðasjúkdóma, lungnasjúkdóma, sykursýki, geðsjúkdóma og meltingarsjúkdóma) sem notar lyf mikið voru skoðuð sérstaklega. Einnig voru könnuð viðhorf peirra sem voru frískir og nota lyf sjaldan.

\section{Efniviður og aðferðir}

The Beliefs about Medicines Questionnaire

BMQ er í tveimur hlutum, sértækur (BMQ-S) og almennur hluti (BMQ-G). Hvor hluti hefur tvo undirhluta (tafla I). BMQ-S eru 10 spurningar. Fyrri undirhluti BMQ-S, specific-necessity (BMQ$\mathrm{SN})$, metur hversu mikla pörf fólk hefur fyrir lyfin sín og hversu mikilvæg peim pykir pau vera til að stuðla að betri heilsu núna 
Tafla I. The Beliefs about Medicines Questionnaire spurningalistinn.

\section{BMQ-Specific (BMQ-S)}

Specific-Necessity (BMQ-SN)

Núverandi heilsa mín veltur á lyfjunum sem ég tek.

Líf mitt væri óbærilegt án lyfjanna sem ég tek.

Ég yrði mjög veik/ur án lyfjanna sem ég tek.

Heilsa mín í framtíðinni veltur á lyfjunum sem ég tek.

Lyfin sem ég tek koma í veg fyrir að mér versni.

Specific-Concern (BMQ-SC)

Mér finnst áhyggjuefni að purfa taka lyf.

Ég hef stundum áhyggjur af langtímaáhrifum lyfjanna sem ég tek.

Ég veit lítið eða ekkert um lyfin sem ég tek.

Lyfin sem ég tek raska lífi mínu.

Ég hef stundum áhyggjur af pví að verða of háð/ur lyfjunum sem ég tek.

\section{BMQ-General (BMQ-G)}

\section{General-Overuse (BMQ-GO)}

Læknar ávísa lyfjum í of miklum mæli.

Náttúruvörur (náttúrulyf, náttúruefni t.d. lýsi, vítamín, sólhattur, remedíur

eða grasalyf) eru öruggari en lyf.

Læknar treysta um of á lyf.

Læknar mundu ávísa minna af lyfjum ef peir verðu meiri tíma með

sjúklingum sínum.

General-Harm (BMQ-GH)

Peir sem taka lyf að staðaldri ættu að gera hlé á lyfjatöku af og til.

Flest lyf eru ávanabindandi.

Lyf gera meiri skaða en gagn.

Öll lyf eru eitur.

og í framtíðinni. Síðari undirhlutinn, specific-concerns (BMQ-SC), er notaður til að meta viðhorf fólks til mögulegra neikvæðra afleiðinga lyfjainntöku og hann mælir áhyggjur tengdar langtímanotkun lyfja, svo sem vegna ávana og annarra truflandi áhrifa. BMQ-G eru 8 spurningar og er ætlaður öllum, hvort sem viðkomandi er á lyfjum eða ekki, og fjallar um viðhorf til lyfja almennt. Undirhlutar almenna hlutans eru general-harm (BMQ-GH) og general-overuse (BMQ-GO). Sá fyrri beinist að skoðunum á mögulegri skaðsemi lyfja. Til að mynda að lyf séu hættuleg, ávanabindandi og að gera skuli hlé á lyfjatöku öðru hverju. Síðari undirhlutinn metur viðhorf til mögulegrar ofnotkunar lyfja og oftrúar á pau af hálfu lækna.

\section{Úrtakið og spurningar}

Úrtakið var fengið úr nethópi Félagsvísindastofnunar Háskóla Íslands og sá hún einnig um framkvæmd netkönnunarinnar. Nethópurinn samanstóð af 5305 einstaklingum á aldrinum 18-75 ára. Upphaflegt úrtak var 1500 Íslendingar á aldrinum 18-75 ára af öllu landinu. Spurningalistinn var sendur út í formi netkönnunar og var slóðin að henni send með tölvupósti á úrtakið. Gögnum var safnað í október-nóvember 2011. Gætt er að pví að nethópurinn endurspegli pjóðina sem allra best. Hópurinn er reglulega uppfærður pannig að hann samsvari dreifingu í pýði með tilliti til kyns, aldurs, búsetu, menntunar og tekna. Með pví að tryggja gæði nethópsins með framangreindum hætti er mögulegt að alhæfa um niðurstöður rannsókna sem byggjast á svörum nethóps Félagsvísindastofnunar.

Spurningalistinn innihélt BMQ í íslenskri pýðingu. Auk pess voru pátttakendur spurðir um notkun lyfja, heilsufar og fleira. Einnig var spurt um kyn, aldur, búsetu og menntun (hæstu prófgráðu sem hefur verið lokið). Pátttakendur sem tóku lyf sjaldnar
Tafla II. Lýðfræðilegar upplýsingar um pátttakendur.

\begin{tabular}{lll}
\hline Breytur & $\mathrm{n}$ & $\%$ \\
\hline Fjöldi & 921 & - \\
\hline Aldur (meðalaldur $45,4 \pm 14,8)^{\star}$ & & \\
\hline $18-24$ & 237 & 26 \\
\hline $25-34$ & 234 & 25 \\
\hline $35-50$ & 226 & 25 \\
\hline $51-75$ & 221 & 24 \\
\hline Kyn & & \\
\hline Konur & 479 & 52 \\
\hline Karlar & 442 & 48 \\
\hline Menntun (hæsta prófgráða sem hefur verið lokið) & & \\
\hline Grunnskólapróf & 186 & 20 \\
\hline Framhaldsskólapróf & 374 & 41 \\
\hline Háskólapróf & 308 & 33 \\
\hline
\end{tabular}

*Aldursdreifing pátttakenda víkur frá aldurssamsetningu Íslendinga samkvæmt Hagstofu Íslands.

en mánaðarlega svöruðu ekki BMQ-S pví talið var ólíklegt að peir hefðu langvinna sjúkdóma og voru pví álitnir frískir. Allir áttu að svara BMQ-G. Pátttakendur gáfu til kynna hversu sammála eða ósammála peir væru hverri fullyrðingu BMQ. Fyrir hverja fullyrðingu BMQ stóðu til boða 5 svarmöguleikar og voru pannig gefin stig frá 1 (mjög ósammála) til 5 (mjög sammála). Fyrir hvorn undirhluta BMQ-S var hægt að fá 5-25 stig og 4-20 stig fyrir BMQG. Hátt stigaskor fyrir BMQ-SN gefur pannig til kynna jákvætt viðhorf gagnvart pví hversu mikilvæg lyfin séu en hátt stigaskor BMQ-SC bendir aftur til pess að fólk hafi áhyggjur af pví að taka inn lyf sín, meðal annars vegna hættu á aukaverkunum og vanabindingu. Hátt stigaskor fyrir BMQ-G gefur til kynna að svarendur taki undir fullyrðingar um skaðsemi og ofnotkun lyfja.

Par sem BMQ-S er ætlaður fólki með langvinna sjúkdóma sem notar lyf talsvert, purfti að greina pennan hóp frá öðrum. Gert var ráð fyrir pví að peir sem höfðu langvinna sjúkdóma tækju lyf að minnsta kosti einu sinni í mánuði. Peir pátttakendur sem sögðust taka lyf, hvort sem pau voru lyfseðilsskyld eða ekki, daglega, vikulega eða mánaðarlega, fengu spurningar BMQ-S. Fyrst var spurt við hvaða sjúkdómi lyfin væru tekin. Hægt var að merkja við fleiri en einn sjúkdóm. Hóparnir voru hjarta- og æðasjúkdómar, lungnasjúkdómar, sykursýki, geðsjúkdómar, meltingarsjúkdómar, illkynja sjúkdómar, ofnæmi og beinpynning. Dæmi um algengustu sjúkdómana í hverjum flokki voru tíunduð fyrir hvern sjúkdómaflokk. Ef viðkomandi pátttakandi hafði langvinnan sjúkdóm sem ekki heyrði til neins af áðurnefndum flokkum, mátti merkja við ótilgreindan sjúkdóm. Leyfi fékkst fyrir rannsókninni frá vísindasiðanefnd (nr. VSN 11-102) og tilkynnt var um hana til Persónuverndar (nr. S5314/2011).

\section{Pýding BMQ listans}

BMQ var pýddur úr ensku yfir á íslensku. Aðferðin sem notuð var við pýðinguna byggist á premur sjálfstæðum pýðingum og síðan er nákvæmni pýðingarinnar athuguð af óháðum aðila. ${ }^{26}$ Lítið sem 
Tafla III. Allir pátttakendur og meðaltal stiga BMQ. Fjöldi peirra sem svöruðu öllum fullyrðingum í hverjum hluta BMQ.

\begin{tabular}{|c|c|c|c|c|c|c|}
\hline & \multicolumn{2}{|c|}{ Allir pátttakendur } & \multicolumn{2}{|c|}{ Pátttakendur með ákveðna langvinna sjúkdóma } & \multicolumn{2}{|c|}{ Frískir pátttakendur } \\
\hline & Meðaltal stiga (SD) & Fjöldi & Meðaltal stiga (SD) & Fjöldi & Međaltal stiga (SD) & Fjöldi \\
\hline BMQ-GO & $13,2( \pm 2,98)$ & 883 & $12,6( \pm 3,04)$ & 331 & $13,9( \pm 2,82)$ & 232 \\
\hline BMQ-GH & $9,29( \pm 3,10)$ & 876 & $8,70( \pm 2,94)$ & 329 & $10,4( \pm 3,26)$ & 232 \\
\hline BMQ-SN & - & - & $20,4(4,15)$ & 398 & - & - \\
\hline BMQ-SC & - & - & $13,0(4,34)$ & 398 & - & - \\
\hline
\end{tabular}

$\mathrm{SD}=$ Staðalfrávik

ekkert ósamræmi var milli pýðinganna priggja og pótti nægilegt að leggja listann fyrir 15 háskólastúdenta til prófunar og ekki var talin pörf á tölfræðiprófum. Að pessu loknu hittust pýðendurnir og fóru yfir pær athugasemdir á BMQ sem bárust frá pátttakendum og komu sér saman um lagfæringar. Aðeins var talin pörf á að breyta lítillega pýðingu á tveimur spurningum listans. Pví næst fóru tveir sérfræðingar á sviði próffræði við Háskóla Íslands, með töluverða reynslu af gildun mælitækja og spurningalistum, yfir BMQ og viðbótarspurningarnar og gerðu athugasemdir.

\section{Úrvinnsla gagna}

Tölfræðiforritið SPSS, 19. útgáfa, var notað við úrvinnslu og greiningu gagna. Stig undirhluta BMQ voru reiknuð með pví að nota heildarstigafjölda. Reiknað var meðaltal og staðalfrávik stiga fyrir alla hluta BMQ. Ef einni eða fleiri fullyrðingum í tilteknum hluta BMQ var ekki svarað, voru ekki reiknuð heildarstig fyrir pann hluta. Próf óháð dreifingu (non-parametric test) voru notuð til að athuga mun á viðhorfi til lyfja milli kyns og aldurs. Mann-Whitney-próf og Kruskal Wallis-próf voru notuð til að athuga hvort tengsl væru milli aldurs, kyns og menntunar og viðhorfs. Petta var bæði kannað fyrir almenn og sértæk viðhorf. Einnig voru borin saman stig BMQ fyrir mismunandi hópa. Hrifstærð (effect size) var reiknuð fyrir pær niðurstöður sem voru tölfræðilega marktækar. Útreikningur á hrifstærð byggðist á SPSS par sem 0,1 = lítil, 0,3= miðlungs og 0,5 = veruleg áhrif. Innri áreiðanleiki BMQ var metinn með alfastuðli (Cronbach's alpha) og hann var 0,673-0,869 sem er ásættanlegt. Marktæknimörk voru sett við alfa=0,05.

\section{Niðurstöður}

Pátttakendur

Svarhlutfallið var 61,4\%; 921 manns af 1500 manna úrtaki svöruðu spurningalistanum. Meðalaldur var 45,4 ár. Fjörutíu og sjö manns (5,1\%) höfðu legið í 1-10 nætur á sjúkrahúsi síðastliðna 12 mánuði og 9 (0,9\%) í fleiri en 10 nætur. Frekari lýðfræðilegar upplýsingar um pátttakendur má sjá í töflu II.

\section{Niðurstöður BMQ}

Stig BMQ-S voru einungis reiknuð fyrir pátttakendur sem heyrðu til eftirtalinna sjúkdómahópa: hjarta- og æðasjúkdóma, lungnasjúkdóma, sykursýki, geðsjúkdóma og meltingarsjúkdóma. Langstærsti hluti pessara pátttakenda, eða 90\%, tók lyf daglega. Stærsti hópurinn var með hjarta-og æðasjúkdóma. Sjúklingahópurinn með ofnæmi $(n=64)$ var ekki talinn með við tölfræðiútreikninga vegna pess að nokkrir pátttakenda með pann sjúkdóm sögðust ekki hafa langvinnan sjúkdóm og vegna pess hve lyfjanotkun hópsins var miklu minni en annarra hópa með langvinna sjúkdóma. Stig voru ekki heldur reiknuð fyrir pá pátttakendur sem sögðust hafa beinpynningu ( $\mathrm{n}=11)$ eða illkynja sjúkdóm $(\mathrm{n}=5)$ pví hóparnir voru fámennir og marktækra niðurstaðna pví ekki að vænta við tölfræðilegan samanburð við aðra hópa. Ennfremur var fólki með aðra langvinna sjúkdóma (n=92) sleppt við útreikning stiga pví ekki var vitað um hvaða sjúkdóma var að ræða og pannig hvorki hægt að setja niðurstöðurnar í innbyrðis samhengi né bera pær saman við aðrar sambærilegar rannsóknir, sem allar skilgreina sína sjúklingahópa vel.

Tafla IV. Fullyrðingar BMQ-G og svörun.

\begin{tabular}{|c|c|c|c|}
\hline \multirow[t]{2}{*}{ Fullyrðingar BMQ-G** } & \multicolumn{3}{|c|}{ Pátttakendur sem voru sammála fullyrðingunum, \% } \\
\hline & $\begin{array}{l}\text { Allir } \\
\text { pátttakendur }\end{array}$ & $\begin{array}{l}\text { Pátttakendur með ákveðna } \\
\text { langvinna sjúkdóma }(n=330)\end{array}$ & $\begin{array}{l}\text { Frískir pátttakendur } \\
\qquad(\mathrm{n}=232)\end{array}$ \\
\hline Læknar ávísa lyfjum í of miklum mæli. (O) & 54,8 & 45,3 & 66,1 \\
\hline Peir sem taka lyf að staðaldri ættu að gera hlé á lyfjatöku af og til. (H) & 21,9 & 14,3 & 36,7 \\
\hline Flest lyf eru ávanabindandi. $(\mathrm{H})$ & 19,6 & 12,4 & 25,9 \\
\hline $\begin{array}{l}\text { Náttúruvörur (náttúrulyf, náttúruefni, til dæmis lýsi, vítamín, sólhattur, remedíur eða } \\
\text { grasalyf) eru öruggari en lyf. (O) }\end{array}$ & 30,4 & 23,2 & 36,5 \\
\hline Lyf gera meiri skaða en gagn. $(H)$ & 5,6 & 4,6 & 8,8 \\
\hline Öll lyf eru eitur. (H) & 7,2 & 6,7 & 9,7 \\
\hline Læknar treysta um of á lyf. (O) & 36,2 & 32,4 & 44,9 \\
\hline Læknar mundu ávísa minna af lyfjum ef peir verðu meiri tíma með sjúklingum sínum. (O) & 49,2 & 42,9 & 55,0 \\
\hline
\end{tabular}

*Samanlagt hlutfall pátttakenda sem voru frekar eða mjög sammála fullyrðingunum.

${ }^{* *} \mathrm{O}$ og $\mathrm{H}$ í sviga stendur fyrir fullyrðingar sem tilheyra BMQ-GO og BMQ-GH.

Hlutfall peirra sem vildu ekki svara fullyrðingum BMQ-G var hvergi yfir $3 \%$ af heildarfjölda pátttakenda. 
Tafla V. Samanburður á stigum BMQ-GO og BMQ-GH miðað við menntun hiá pátttakendum sem voru með ákveðna langvinna sjúkdóma og peim sem voru frískir. Taflan sýnir p-gildi og hrifstærð (aðeins reiknuð par sem marktækur munur fannst).

\begin{tabular}{ccccc}
\hline \multirow{2}{*}{ Hópur } & \multicolumn{4}{c}{ Menntun } \\
\cline { 2 - 5 } & BMQ-GO & Hrifstærð & BMQ-GH & Hrifstærð \\
\hline L & $0,006^{*}$ & 0,21 & 0,080 & \\
\hline F & $\leq 0,0001^{*}$ & 0,42 & $\leq 0,0001^{*}$ & 0,32 \\
\hline allir & $0,009^{*}$ & 0,12 & $\leq 0,0001^{*}$ & 0,24 \\
\hline
\end{tabular}

*Marktækur munur

L: Pátttakendur með ákveðna langvinna sjúkdóma og F: frískir pátttakendu

Stig undirhluta BMQ-G; BMQ-GH og BMQ-GO, voru reiknuð fyrir alla pátttakendur. Síðan voru viðhorf fólks með hjarta- og æðasjúkdóma, lungnasjúkdóma, sykursýki, geðsjúkdóma og meltingarsjúkdóma skoðuð sérstaklega og flokkuð í sérhóp sem gekk undir nafninu „pátttakendur með ákveðna langvinna sjúkdóma“. Einnig voru stig frískra pátttakenda (sem tóku lyf sjaldnar en mánaðarlega) skoðuð nánar (sjá töflu III). Samanlagður fjöldi pátttakenda í pessum tveimur hópum, pað er pátttakenda með ákveðna langvinna sjúkdóma og frískra pátttakenda, er pví nokkru minni en heildarfjöldi pátttakenda, eins og fram kemur í töflu III. Milli pessara tveggja hópa mátti finna marktækan mun á stigum BMQ-GH og BMQ-GO ( $\mathrm{p} \leq 0,0001$ og $\mathrm{p} \leq 0,0001)$.

Í töflu IV má sjá að stór hluti pátttakenda, bæði samanlagt og í hverjum hópi fyrir sig, var sammála eftirfarandi fullyrðingum BMQ-GO: „læknar ávísa lyfjum í of miklum mæli“, „læknar mundu ávísa minna af lyfjum ef peir verðu meiri tíma með sjúklingum sínum“ og „lækknar treysta um of á lyf“. Pátttakendur sem voru frískir voru meira sammála pessum fullyrðingum en peir sem voru með langvinna sjúkdóma. Minnihluti pátttakenda var sammála fullyrðingum BMQ-GH, en flestir sem tóku undir pær voru frískir. Af öllum pátttakendum voru 5,6\% og 7,2\% sammála fullyrðingunum „lyf gera meiri skaða en gagn“ og „,̈ll lyf eru eitur".
Ef viðhorf allra pátttakenda eru tekin saman, má sjá að fólk með minni menntun hafði neikvæðara viðhorf til lyfja. Pannig tóku pátttakendur með grunnskólapróf frekar undir fullyrðingar um skaðsemi lyfja og ofnotkun peirra en fólk sem lokið hafði háskólaprófi (tafla V). Ekki fannst marktækur munur á viðhorfum almennt eftir aldri og kyni pátttakenda.

Ef litið var á heildarsvörun BMQ-S fyrir sjúkdómahópana 5 (sjá töflu VI) má sjá að flestir pátttakendur voru sammála eftirfarandi fullyrðingunum sem sneru að mikilvægi lyfja peirra: „núverandi heilsa mín veltur á lyfjunum sem ég tek“ (84\%) og „,lyfin sem ég tek koma í veg fyrir að mér versni“ (81\%). Stór hluti pátttakenda hafði áhyggjur af pví að taka lyf (52,6\%) og langtímaáhrifum peirra $(40,3 \%)$.

\section{Umræður}

Niðurstöður pessarar rannsóknar sýna að porri Íslendinga er jákvæður gagnvart lyfjum og treystir peim yfirleitt. Fólk með ákveðna langvinna sjúkdóma var jákvæðara en aðrir pátttakendur og tók síður undir fullyrðingar um skaðsemi og ofnotkun lyfja en ekki var marktækur munur á milli mismunandi sjúklingahópa. Menntun hafði mikil áhrif á viðhorfin með peim hætti að fólk með minni menntun bar minna traust til lyfja. Fyrri rannsóknir hafa gefið svipaðar niðurstöður., ${ }^{9,27}$ Hvorki kyn né aldur hafði áhrif á viðhorfin.

Fólk tók mun frekar undir fullyrðingar sem sneru að ofnotkun lyfja heldur en skaðsemi af völdum peirra. Рað kom ekki á óvart pví undanfarið hefur verið mikið talað í pjóðfélaginu um ofnotkun lyfja. Efasemdir um að metýlfenídati sé ávallt ávísað viturlega og áhyggjur af óhóflegri notkun sýklalyfja eru dæmi par um. Prátt fyrir að minnihluti hafi tekið undir að lyf væru skaðleg, pykir áhyggjuefni að 5,6\% pátttakenda telji lyf gera meiri skaða en gagn og að 7,2\% telji öll lyf vera eitur. Fólk með langvinna sjúkdóma hafði mun jákvæðara viðhorf til lyfja en frískir. Ástæðurnar fyrir pví gætu verið pær að veikt fólk hefur upplifað hversu mikið lyfin

Tafla VI. Fullyrðingar BMQ-S og svörun pátttakenda með ákveđna langvinna sjúkdóma (L).

\begin{tabular}{|c|c|c|c|c|c|c|}
\hline \multirow[t]{2}{*}{ Fullyrðingar BMQ-S** } & \multicolumn{6}{|c|}{ Hlutfall pátttakenda sem voru sammála í hópum, \% } \\
\hline & $L^{* \star *}$ & $\begin{array}{l}\text { Hjarta- og } \\
\text { æðasjúkdómar }\end{array}$ & $\begin{array}{l}\text { Lungna- } \\
\text { sjúkdómar }\end{array}$ & Sykursýki & $\begin{array}{c}\text { Geð- } \\
\text { sjúkdómar }\end{array}$ & $\begin{array}{l}\text { Meltingar- } \\
\text { sjúkdómar }\end{array}$ \\
\hline Núverandi heilsa mín veltur á lyfjunum sem ég tek. (N) & 84,3 & 89 & 72,2 & 93,1 & 83,6 & 83,1 \\
\hline Mér finnst áhyggjuefni að purfa að taka lyf. (C) & 52,6 & 53,8 & 41,7 & 42,8 & 51,6 & 61,8 \\
\hline Líf mitt væri óbærilegt án lyfjanna sem ég tek. (N) & 60,8 & 57,1 & 80,0 & 85,2 & 66,1 & 68,0 \\
\hline Ég yrði mjög veik/ur án lyfjanna sem ég tek. (N) & 56,5 & 57,2 & 68,5 & 92,6 & 60,0 & 57,4 \\
\hline Ég hef stundum áhyggjur af langtímaáhrifum lyfjanna sem ég tek. (C) & 40,3 & 41,2 & 27,0 & 39,3 & 44,2 & 52,0 \\
\hline Ég veit lítið eða ekkert um lyfin sem ég tek. (C) & 25,6 & 25,2 & 22,8 & 29,6 & 18,4 & 28,4 \\
\hline Heilsa mín í framtíđinni veltur á lyfjunum sem ég tek. (N) & 69,2 & 76,6 & 55,6 & 92,9 & 55,8 & 66,3 \\
\hline Lyfin sem ég tek raska lífi mínu. (C) & 9,2 & 7,2 & 13,9 & 7,6 & 15,0 & 10,9 \\
\hline Ég hef stundum áhyggjur af pví að verða of háð/ur lyfjunum sem ég tek. (C) & 18,5 & 17,1 & 25,0 & 14,8 & 21,7 & 27,1 \\
\hline Lyfin sem ég tek koma í veg fyrir aơ mér versni. (N) & 81,2 & 82,5 & 86,1 & 88,5 & 85,0 & 80,0 \\
\hline
\end{tabular}

*Samanlagt hlutfall pátttakenda sem voru frekar eða mjög sammála fullyrðingunum.

${ }^{* *} \mathrm{~N}$ og $\mathrm{C}$ í sviga stendur fyrir fullyrðingar sem tilheyra BMQ-SN og BMQ-SC.

***Hlutfall sem vildu ekki svara fullyrðingum BMQ-S var hvergi yfir $4 \%$. 
geta raunverulega hjálpað og hefur pví öðlast skilning á pví hvað pað hefði slæmar afleiðingar að taka pau ekki. Fólk með langvinna sjúkdóma hefur auk pess mikil samskipti við lækna og pað getur haft áhrif á viðhorfin pví gott samband læknis og sjúklings getur aukið traust og trú á lyfjameðferðinni. ${ }^{3,10}$ Svo eru líklega sumir sem forðast eftir fremsta megni að taka lyf nema í mestu neyð vegna tortryggni í garð peirra. Skortur á pekkingu vegur hér pungt og er einn af peim páttum sem geta valdið vantrú og efasemdum gagnvart lyfjum. Mikið hefur verið fjallað um samband lækna og lyfjafyrirtækja og áhrif pess á viðhorf fólks til lyfja. Pví hefur verið haldið fram að lyfjafyrirtæki hafi áhrif á dómgreind lækna og hegðun peirra, jafnvel ásamt pví að lyfjaávísanir verði óskynsamlegar. ${ }^{28}$ Fólk gerir sér grein fyrir pessum tengslum og getur pað orðið til pess að skerða traust á ráðum læknis varðandi lyf og kveikja efasemdir um hversu mikilvægt sé að taka pau. ${ }^{3}$ Viðhorf frískra einstaklinga til lyfja hafa lítið verið könnuð með BMQ-spurningalistanum erlendis. Pær rannsóknir sem hafa verið gerðar hafa beinst að mismunandi heilbrigðisstéttum ${ }^{29,30}$ og viðskiptavinum apóteka. ${ }^{27}$ Einnig hafa viðhorf sænsks almennings til lyfja verið könnuð par sem almenni hluti BMQ-listans var notaður. Viðhorf Svía, líkt og Íslendinga, voru einnig jákvæðari meðal fólks sem notaði lyfseðilsskyld lyf. ${ }^{31}$

Heildarviðhorf fólks með langvinna sjúkdóma var svipað milli allra hópa, bæði hvað varðar mikilvægi lyfja og áhyggjur vegna lyfjameðferðar. Viðhorf íslensku pátttakendanna með vissa langvinna sjúkdóma voru borin saman við niðurstöður svipaðrar rannsóknar frá Pýskalandi par sem einnig var notast við BMQ. ${ }^{25}$ Viðhorf til lyfja almennt voru frekar svipuð milli rannsókna en munur var á viðhorfi til eigin lyfja, til dæmis var meira ríkjandi viðhorf meðal pjóðverja að peim pættu lyf sín mikilvæg. Viðhorf Íslendinga með geðsjúkdóma voru borin saman við viðhorf bandarískra punglyndissjúklinga par sem einnig var notast við BMQ. ${ }^{32}$ Pátttakendur bandarísku rannsóknarinnar virtust hafa áhyggjur af mögulegri ofnotkun lyfja líkt og Íslendingar. Í báðum rannsóknum tóku flestir pátttakendur undir fullyrðingarnar: „læknar ávísa lyfjum í of miklum mæli“, „læknar mundu ávísa minna af lyfjum ef peir verðu meiri tíma með sjúklingum sínum“ og „læknar treysta um of á lyf“. Íslendingar og Bandaríkjamenn tóku síður undir fullyrðingar um skaðsemi lyfja. Íslendingar með langvinna sjúkdóma voru flestir sammála pessum tveimur fullyrðingum um eigin lyf: „lyfin sem ég tek koma í veg fyrir að mér versni“ og „núverandi heilsa mín veltur á lyfjunum sem ég tek“. Í bandarísku rannsókninni voru flestir sammála fyrrnefndu fullyrðingunni en álíka margir sammála peirri síðarnefndu og fullyrðingunni: „ég hef stundum áhyggjur af langtímaáhrifum lyfjanna sem ég tek." Pessar niðurstöður gefa góða hugmynd af viðhorfi fólks með geðsjúkdóma sem er á heildina litið frekar jákvætt.

Fleiri rannsókna er pörf á viðhorfum fólks til lyfja hérlendis. Áhugavert væri að taka fyrir betur skilgreinda sjúklingahópa, til dæmis fólk með astma og háprýsting. Pá væri líka hægt að gera samanburð við erlendar rannsóknir af svipuðum toga. Einnig væri áhugavert að kanna viðhorf ákveðinna heilbrigðisstétta, svo sem lækna, hjúkrunarfræðinga og lyfjafræðinga. Aldursdreifing pátttakenda vék nokkuð frá aldurssamsetningu pjóðarinnar en pað ætti pó ekki að trufla meginniðurstöður rannsóknarinnar. Notast var við eigin frásagnir og mat pátttakenda á sjúkdómsástandi sínu. Aðferðin er pægileg en ekki mjög nákvæm. Best hefði verið að fá upplýsingar um sjúkdómsgreiningar úr sjúkraskrám. Sjúkdómaflokkarnir voru skilgreindir mjög gróflega og sumpart háðir túlkun hvers og eins pátttakanda, sem er vissulega veikleiki í aðferð rannsóknarinnar. Ef peir hefðu verið tilgreindir nánar hefði pað getað vafist fyrir pátttakendum ásamt pví að of fáir pátttakendur yrðu í hverjum flokki, eins og raunin varð með til dæmis beinpynningu og illkynja sjúkdóma. Helstu styrkleikar pessarar rannsóknar eru peir að úrtakið er stórt og pví dreift um alla landshluta og svarhlutfallið gott. Niðurstöðurnar gefa pví góða mynd af viðhorfum Íslendinga til lyfja og lyfjameðferðar.

Að kortleggja viðhorf fólks til lyfja getur verið gagnlegt til að bæta meðferð við langvinnum sjúkdómum. ${ }^{1}$ Með aukinni fræðslu um lyf væri mögulega hægt að draga úr misskilningi meðal almennings og bæta viðhorf fólks til lyfja enn frekar. Niðurstöður pessarar rannsóknar gætu skapað grundvöll umbótastarfs fyrir klíníska vinnu og til hagræðingar fyrir heilbrigðiskerfið. Slík vinna gæti stuðlað að málefnalegri umræðu um pátt lyfja í meðferð sjúkdóma, vanda tengdan meðferðarfylgni og bætt samskipti lækna við sjúklinga og lyfjafyrirtæki.

\section{Pakkir}

Lundbeck Export A/S fær pakkir fyrir veittan fjárstyrk. Jóhann Axel Andersen pýðandi og Pétur Guðmann Guðmannsson læknir fá pakkir fyrir íslenska pýðingu á BMQ. Daníel Pór Ólason prófessor og Porbjörn Broddason prófessor fá pakkir fyrir ráðgjöf við gerð spurningalistans í heild sinni. Halldóru Jónsdóttur lækni er pakkað fyrir ráðgjöf. Sesselja Sigurborg Ómarsdóttir prófessor og Pórdís Kristmundsdóttir prófessor fá pakkir fyrir ráðleggingar. 


\section{Heimildir}

1. Horne R, Weinman J. Patients' beliefs about prescribed medicines and their role in adherence to treatment in chronic physical illness. J Psychosom Res 1999; 47: 555-67.

2. George J. Factors Associated With Medication Nonadherence in Patients With COPD. Chest 2005; 128 : 3198.

3. Goff SL, Mazor KM, Meterko V, Dodd K, Sabin J. Patients' beliefs and preferences regarding doctors' medication recommendations. J Gen Intern Med 2008; 23: 236-41.

4. Horne R, Weinman J, Hankins M. The beliefs about medicines questionnaire: The development and evaluation of a new method for assessing the cognitive representation of medication. Psychol Health 1999; 14: 1-24.

5. Allen LaPointe NM, Ou FS, Calvert SB, Melloni C, Stafford JA, Harding T, et al. Changes in beliefs about medications during long-term care for ischemic heart disease. Am Heart J 2010; 159: 561-9.

6. Horne R, Graupner Ld, Frost S, Weinman J, Wright SM, Hankins M. Medicine in a multi-cultural society: the effect of cultural background on beliefs about medications. Soc Sci Med 2004; 59: 1307-13.

7. Barnes L, Moss-Morris R, Kaufusi M. Illness beliefs and adherence in diabetes mellitus: a comparison between Tongan and European patients. N Z Med J 2004; 117: U743.

8. Magadza C, Radloff SE, Srinivas SC. The effect of an educational intervention on patients' knowledge about hypertension, beliefs about medicines, and adherence. Res Soc Admin Pharm 2009; 5: 363-75.

9. Isacson D, Bingefors K. Attitudes towards drugs--a surve in the general population. Pharm World Sci 2002; 24: 104-

10. Day JC, Bentall RP, Roberts C, Randall F, Rogers A, Cattel D, et al. Attitudes toward antipsychotic medication: the impact of clinical variables and relationships with health professionals. Arch Gen Psychiatry 2005; 62: 717-24.
11. Benson J, Britten N. Patients' decisions about whether or not to take antihypertensive drugs: qualitative study. BMJ 2002; 325: 873 .

12. Grande D, Shea JA, Armstrong K. Pharmaceutical industry gifts to physicians: patient beliefs and trust in physicians and the health care system. J Gen Intern Med 2011; 27: 274-9.

13. Green MJ, Masters R, James B, Simmons B, Lehman E. Do gifts from the pharmaceutical industry affect trust in physicians? Fam Med 2012; 44: 325.

14. Horne R, Weinman J. Self-regulation and self-management in asthma: exploring the role of illness perceptions and treatment beliefs in explaining non-adherence to preventer medication. Psychol Health 2002; $17: 17$.

15. Shiri C, Srinivas SC, Futter WT, Radloff SE. The role of insight into and beliefs about medicines of hypertensive patients. Cardiovasc J Afr 2007; 18: 353-7.

16. Ruppar TM, Dobbels F, De Geest S. Medication Beliefs and Antihypertensive Adherence Among Older Adults: A Pilot Study. Geriatr Nurs 2012;33:89-95.

17. Maguire LK, Hughes CM, McElnay JC. Exploring the impact of depressive symptoms and medication beliefs on medication adherence in hypertension--a primary care study. Patient Educ Couns 2008; 73: 371-6.

18. Byrne M, Walsh J, Murphy AW. Secondary prevention of coronary heart disease: Patient beliefs and health-related behaviour. J Psychosom Res 2005; 58: 403-15.

19. Aikens JE, Nease DE, Nau DP, Klinkman MS, Schwenk TL. Adherence to Maintenance-Phase Antidepressant Medication as a Function of Patient Beliefs About Medication. Ann Fam Med 2005: 3: 23-30.

20. Beck E-M, Cavelti M, Kvrgic S, Kleim B, Vauth R. Are we addressing the 'right stuff' to enhance adherence in schizophrenia? Understanding the role of insight and attitudes towards medication. Schizophr Res 2011; 132: $42-9$

21. Grunfeld. Adherence beliefs among breast cancer patients taking tamoxifen. Patient Educ Couns 2005; 59: 97.
22. Bhattacharya D, Easthall C, Willoughby KA, Small M, Watson S. Capecitabine non-adherence: Exploration of magnitude, nature and contributing factors. J Oncol Pharm Pract 2012; 18: 333-42.

23. Kumar K, Gordon C, Toescu V, Buckley CD, Horne R, Nightingale PG, et al. Beliefs about medicines in patients with rheumatoid arthritis and systemic lupus erythematosus: a comparison between patients of South Asian and White British origin. Rheumatology 2008; 47: 690-7.

24. Neame R, Hammond A. Beliefs about medications: a questionnaire survey of people with rheumatoid arthritis. Rheumatology 2005; 44: 762-7.

25. Mahler C, Hermann K, Horne R, Jank S, Haefeli WE, Szecsenyi J. Patients' Beliefs about Medicines in a primary care setting in Germany. J Eval Clin Pract 2010; 18: 409-13.

26. Guðmundsson E. Pýðing og staðfærsla sálfræðilegra prófa. Sálfræðiritið 2006; 10: 23-40.

27. Mårdby A-C, Åkerlind I, Jörgensen T. Beliefs about medicines and self-reported adherence among pharmacy clients. Patient Educ Couns 2007; 69: 158-64.

28. Wazana A. Physicians and the Pharmaceutical Industry. JAMA 2000; 283: 373-80.

29. Mardby AC, Akerlind I, Hedenrud T. General beliefs about medicines among doctors and nurses in out-patient care: a cross-sectional study. BMC Fam Pract 2009; 10: 35.

30. Jorgensen TM, Andersson KA, Mardby AC. Beliefs about medicines among Swedish pharmacy employees. Pharm World Sci 2006; 28: 233-8.

31. Andersson Sundell K, Jönsson AK. Beliefs about medicines are strongly associated with medicine-use patterns among the general population. Int J Clin Pract 2016; 70: 277-85.

32. Brown C, Battista DR, Bruehlman R, Sereika SS, Thase ME, Dunbar-Jacob J. Beliefs about antidepressant medications in primary care patients: relationship to self-reported adherence. Med Care 2005; 43: 1203-7.

\section{ENGLISH SUMMARY}

\section{Icelanders' beliefs about medicines. Use of BMQ}

Hlíf Vilhelmsdóttir ${ }^{1,2}$, Magnús Jóhannsson²

Objective: To study beliefs held by the general public in Iceland about medicines.

Methods: The Beliefs about Medicines Questionnaire was used to explore Icelanders' beliefs about medicines. A sample of 1500 Icelandic citizens, aged 18-75, obtained from the Social Science Research Institute was given The Beliefs about Medicines Questionnaire.

Results: The response rate was $61.6 \%$. Most Icelanders have positive beliefs about their medication as well as general trust. Those who suffer from chronic diseases are more positive towards medicines than others and less inclined to view them as excessively used and harmful. Higher level of education predicts more positive beliefs towards medication and vice versa. Gender and age do not seem to affect such beliefs. Conclusion: Gaining a better understanding of people's beliefs about medicines and what determines these beliefs can be of considerable value in the search for ways to improve therapy and adherence, especially for those suffering from chronic diseases. Promoting education for the general public about medicines might result in less misunderstanding among patients and subsequently better grounded beliefs and more adequate therapeutic adherence.

'Faculty of Pharmaceutical Sciences, University of Iceland, Reykjavik, Iceland. ${ }^{2}$ Department of Pharmacology and Toxicology, Faculty of Medicine, University of Iceland, Reykjavik, Iceland.

Key words: beliefs, medicines, Icelanders, BMQ, survey.

Correspondence: Hlif Vilhelmsdóttir, hlif84@gmail.com 